\title{
Attitudes toward Inclusive Education among School Teachers: A Comparative Study
}

\author{
Arun $\operatorname{Kumar}^{1} *$, Dr. Punam Midha ${ }^{2}$
}

\section{ABSTRACT}

Inclusive education in India has recently received a momentum .A willingness on the part of Teachers to support all children in the mainstream classroom; including with special needs is the hallmark of inclusive education. Thus teacher's attitudes toward inclusive education play a pivotal role in its success. In this way, the present study is an attempt to assess and compare the attitudes of mainstream and special education school teachers towards inclusive education .A purposive sample of 300 regular school teachers consisting of 150 teachers from mainstream and 150 teachers from special schools of Delhi-NCR (Noida, Ghaziabad, Delhi, Faridabad) of both male and female aged 24-45 yrs was drawn for research purpose. Attitudes toward Inclusive Education Scale (ATIES) developed by Wilczenski, F.L (1992), containing 16 items was used to measure their attitudes toward inclusive education. Descriptive and inferential statistics (t-test) were used to assess and compare the attitudes of teachers of mainstream and those of special school. The results indicated that teachers of mainstream school have more favourable attitudes than those of special schools, which may be one of the major causes of slow success of this system in India.

Keywords: Inclusive education, Mainstream school teachers, Special school teachers, Attitudes

The world is changing at a dizzying pace and things are no longer what they used to be earlier. Every child irrespective of the disability has a right to education in an institution, where the normal children used to get. As per census of India (2011), the percentage of disabled person in India has increased both in rural and urban areas. Out of the total population $2.1 \%$ persons are suffering from disability, out of which 1.14\% (0-4 yrs), 1.54\% (5-9yrs) and 1.82\% (10-19yrs) are disabled children. In such a prevailing pathetic situation, the launching of inclusive education scheme is just to promote opportunities for all children to participate, learn and have equal

\footnotetext{
${ }^{1}$ Research scholar, Department of Psychology, M.D.U Rohtak, Haryana, India

${ }^{2}$ Professor, Department of Psychology, M.D.U Rohtak, Haryana, India

*Responding Author

Received: February 22, 2017; Revision Received: March 24, 2017; Accepted: March 29, 2017

(C) 2017 Kumar A, Midha P; licensee IJIP. This is an Open Access Research distributed under the terms of the Creative Commons Attribution License (www.creativecommons.org/licenses/by/2.0), which permits unrestricted use, distribution, and reproduction in any Medium, provided the original work is properly cited.
} 


\section{Attitudes toward Inclusive Education among School Teachers: A Comparative Study}

treatment irrespective of their mental /physical disabilities. The main aim of such scheme is to eradicate the negative stereotypes towards special educational needs children.

The principle of inclusive education was first adopted at world conference on " Special Needs Education: Access and Quality” which was held in Salamanca ,Spain (1994).It was further strengthen at the world education forum (Dakar,2000), however a decade ago a census has emerged among Indian intellectuals and pedagogies for adopting inclusive education in mainstream schools. However owing to lack of up-to-date knowledge, educational access and technology, disabled children in India were treated as unwanted and hence segregated from other children, so they received and are still receiving their education in special schools. However in recent times, there has been a tremendous shift towards having children with disabilities to carry out their studies in the same school where the normal children used to receive. It is not only the alternative measure for children with special needs for wants of separate special schools for these children, rather than it is psychologically well thought strategy for their holistic development. The Indian government continued to include the children with special needs under several of their education initiatives including the Sarva Shiksha Abhiyan ( SSA,2001)and the National Curriculum Frame Work(NCF,2005).NCF(2005) has emphasized upon the implementation of policy of inclusion throughout the educational systems in the country. It focused upon the acceptance of responsibility to extra care of children with special needs, while removing various types of barriers such as physical, social, emotional and attitudinal etc. They further emphasized that work, learn and play together should be the motto of each educational institution in India. Team work consisting of teachers, parents and students irrespective of their disability should be appraised and strengthened .Further till date focus is given on equality of quality of education to be imparted to each child. (Millennium development goals,2015).There are the several national and local NGO's that champion the cause of children with disabilities and provide specific resource centers in support of inclusive education. The general philosophy behind the start of such education system is to empower and develop free of guilt and inferiority complex among children with special needs owing to healthy relationship fostered among such children, teacher \& non disabled children. The present education system has been re-engineered to respond to the pupil's diversity and acknowledges the responsiveness to the diverse needs of all children .Such system is no longer defined as a placement but as a system of support provided to help \& address the needs of a subset of students [Stainback \& Stainback ,1996] ,who fosters a sense of belongingness with other normal children .Thus the main goal of inclusive education is to break down the barriers, which separate general \& special education \& to inculcate the feelings among disable students as an active member of the general education classroom.

The awareness about inclusive education in schools in India is still at infancy stage .The success of such education of students with special educational needs has been a big challenge for the administrators, who are skeptical about imparting education to both normal \& disable children in 


\section{Attitudes toward Inclusive Education among School Teachers: A Comparative Study}

the same class room. They are facing many challenges such as preparedness of teachers for inclusive education, imparting of training to teachers to handle successfully such students, lack of flexibility in the course curriculum, classroom size, bullying of such children, and need of extra attention from the teacher to such children \& consequently promoting an environment, where personal development, social skills \& students’ participation to be strongly encouraged. All above mentioned issues related to inclusive education have been explored by the researchers. There are plethora of studies, which have found unfavourable attitudes of teachers towards inclusive education. (Glaubman \& Lifshitz,2001; Mushoriwa, 2001; Singh \& Alur 2001; Tesfaye, 2005; Alghazo \& Gaad, 2004;Singal,2006 b;Chhabra, Srivastava \& Srivastava,2010;). The negative attitude of teachers toward inclusive education may be attributed to teacher's lack of skill, fear of handling such students. On the contrary there is a wealth of literature ,which focused upon the favourable attitudes of teachers towards inclusive education ( Beltran, 1995 ; Forlin, 1995 ; Padeliadu,et al.,1997; Croll \& Moses, 2000 ; Johnson, 2001;Tesfye,2005 ; Whyte, 2005 ; Ali, Mustapha \& Jelas, 2006 ; Hodkinson,2006 ; Forlin \& Sharma, 2007 ;Khan, 2007). Almost all these studies have revealed the fact that positive attitude towards inclusive education depends upon teacher's efficacy, experience, training, adequate flexibility in course curriculum and type of disability, class size i.e. appropriate setting along with optimum teacher student ratio i.e. 6:1 etc. Though the journey towards Inclusive education in India has begun yet its speed is too slow to be implemented in every corner of the country. For its successful implementation there is an utmost need to explore the attitudes of teachers toward inclusive education because they are key service providers in handling such students. So the present researcher has attempted to select the research problem to highlight and compare the mainstream and special school teacher's attitudes toward inclusive education. After selecting the research problem, the following objective was taken into consideration.

\section{Objective}

- To assess and compare the attitudes of mainstream and special school teachers toward inclusive education.

\section{Hypothesis}

On the basis of above objective following hypothesis was formulated:

- There would be a significant difference in the attitudes of mainstream and special education school teachers toward inclusive education.

\section{Sample}

A purposive sample of 300 primary and secondary school teachers (150 from mainstream, and 150 from special school ) both male and female was taken from Delhi NCR (Noida,Ghaziabad, Delhi, Faridabad) with the following inclusion and exclusion criteria: 


\section{Inclusion criteria}

1. Special school having students of physical, behavioural and social disabilities.

2. Male and Female teachers.

3. Teachers from government and private schools at primary and secondary level.

\section{Exclusion criteria}

1. The teacher who himself/herself is disabled would be avoided.

2. Teachers on contract or daily wages would be avoided.

\section{Tool}

In the present study the following tool was used:

Attitudes toward Inclusive Education Scale (ATIES by Wilczenski, F.L 1992): It contains 16 items .It was designed to elicit teachers' attitudes toward the inclusion of students with various disabilities into regular classrooms. This 16-item scale measures teacher's attitudes toward four aspects of inclusive education: social, physical, academic and behavioral. Participants rate their responses on a likert scale ( $1=$ strongly disagree, $6=$ strongly agree). The scores range from 16 to 96, with a lower score indicating a less favorable attitude and a higher score scale indicates a most favorable attitude.Wilczenski analyzed the reliability of the ATIES scale and reported a Cronbach ${ }^{\text {ee }}$ Alpha value of 0.92 (Kuyini \& Desai,2007).

\section{Procedure}

First of all the consent from teachers of both mainstream and special schools were taken. The rapport was established with teachers and questionnaire was administered after giving relevant instructions. Scoring was done as per norms of the questionnaire.

\section{RESULTS AND DISCUSSION}

The main aim of the study was to assess and compare the attitudes of mainstream and special school teachers toward inclusive education.

Table 1: Descriptive statistics (Mean \& S.D) of the scores obtained on the attitudes (overall) toward inclusive education amongst school teachers.

\begin{tabular}{|llrcc|}
\hline S.No. & Group(category of teachers) & mean & S.D & Possible range scores \\
\hline 1. & Mainstream school teachers & 65.5333 & 5.88898 & \\
2. & Special school teachers & 57.8000 & 5.96297 & $16-96$ \\
\hline
\end{tabular}

The Table 1 indicates that the teachers of mainstream school scored quite higher than those of special school, which revealed that teachers of mainstream school are having more favorable attitudes (overall) toward inclusive education than those of special school teachers. 
Attitudes toward Inclusive Education among School Teachers: A Comparative Study

In order to find out the statistical significant difference of mainstream and special school teacher's and attitudes toward inclusive education, t-test was computed and has been shown in Table 2.

Table 2: t-value of scores obtained on attitudes toward inclusive education of mainstream vs special school teachers.

\begin{tabular}{|c|c|c|c|c|c|}
\hline S.No. & Group(category of teachers) & Mean & SED & df & $\mathbf{t}$ \\
\hline 1. & Mainstream school teachers & 65.5333 & .48083 & \multirow{2}{*}{298} & \multirow[b]{2}{*}{$11.301^{* *}$} \\
\hline 2. & Special school teachers & 57.8000 & .48687 & & \\
\hline
\end{tabular}

Table2: clearly shows the significant difference $(\mathrm{t}=11.301, \mathrm{p}<.001)$ in overall attitudes toward inclusive education of mainstream teachers with those of special school. In this way hypothesis which stated "There would be a significant difference in the attitudes of mainstream and special education school teachers toward inclusive education "is verified. The reason of more positive attitudes of mainstream school teachers than those of special school may be attributed to have a very limited knowledge of inclusive education and ignorant about the problems, actually faced while handling the children with special needs. Theoretically on the surface level, the scheme of inclusive education appears to be very appealing, which no doubt decreases the negative stereotype towards the education of special children. Another reason may be attributed to teacher's perception of self efficacy, which may have a significant impact of their ability to accept the challenges inherent in including disable children with normal students.

Further the positive attitudes of such teachers toward inclusive education may be explained on the basis of the principle of instrumental conditioning, where their favourable attitudes ,toward inclusive education are approved or encouraged by the concerned authorities, such thinking patterns are internalized by them, hence are expressed time \& again. As per social learning theorists due to observational learning, where teachers of the same school appreciate the scheme of inclusive education they also follow their perspective. Further on the basis of functionalist theory, it may be inferred that they showed favourable attitudes because it increases social welfare benefits \& expressed their basic values, which positively reinforced their self image. In this way attitudes serve to protect them from acknowledging harsh realities of life \& hence attitude act as defense mechanism. Further as per reasoned action theory, their favorable attitudes may be explained on the basis of their subjective norms, which are based on the evaluation \& strength of a belief regarding inclusive education. In other words their subjective norms are contingent upon their normative belief (i.e. thinking based on what others expect from them) \& motivation to comply (which depends upon the importance given by others towards an 
issue).The present findings are in line with those of early findings which also examined favourable attitudes of teachers toward inclusive education.(Beltran,1995 ; Forlin, 1995;Padeliadu,et al.,1997; Croll, et al.,2000; Johnson,2001; Tesfye,2005 ;Whyte,2005; Ali,,et al.,2006; Hodkinson,2006; Forlin ,et al., 2007 ;Khan, 2007).

The less favorable attitudes of teacher of the special school education may be due to their "powerful negative effect of experience "with children with special needs (Self perception theory). Further the formation of less favorable attitudes toward inclusive education may be explained on the basis of classical conditioning paradigm, where teaching and handling of the children with special need led to the development of fear about the successful interaction and relationship with them. Further such attitude may be due to inconsistency between attitude and behavior, which may have caused tension (Cognitive Dissonance Theory). It may be due to lack of appropriate training to handle such children, large class size, lack of flexibility in curriculum and lack of resources etc. The present findings are in line with those of previous studies which reported unfavourable attitudes of teachers toward inclusive education.(Beltron,1995; Soodak, Podell, Lehman, 1998; croll et al.,2000;Singh \& Alur, 2001; Kristensen,Onen \& Loican ,2003 ;Gaad,2004; Tesfye,2005; Ali et al.,2006; Chhabra et al.,2010;Forlin et al.,2007; Srivastava, 2010).

After exploring and comparing the overall attitudes of mainstream and special school teachers toward children with various disabilities, the depth analysis was also carried out to explore their attitudes (overall) toward children with various disabilities separately. Descriptive as well as inferential statistics were computed and have been shown in Table 3.

Table No.3: Mean, SD and t-values of the scores obtained on attitude towards children with various disabilities.

\begin{tabular}{|c|c|c|c|c|c|c|c|}
\hline S.No. & $\begin{array}{l}\text { Group } \\
\text { (Category of } \\
\text { school teachers) }\end{array}$ & $\begin{array}{l}\text { Attitudes toward the } \\
\text { type of disability }\end{array}$ & Mean & SD & SED & df & $\mathbf{t}$ \\
\hline & MSST & SOCIAL & 19.313 & 2.4690 & .2016 & & \\
\hline 1. & SST & SOCIAL & 12.833 & 2.3557 & .1923 & 298 & $23.257 * *$ \\
\hline \multirow[t]{2}{*}{2.} & MSST & PHYSICAL & 13.500 & 3.2081 & .2619 & & \\
\hline & SST & PHYSICAL & 17.067 & 2.6789 & .2187 & $288.815^{*}$ & $10.451 * *$ \\
\hline \multirow[t]{2}{*}{3.} & MSST & ACADEMIC & 15.773 & 3.7059 & .3026 & $274.86^{*}$ & $1.398 \mathrm{NS}$ \\
\hline & SST & ACADEMIC & 15.247 & 2.7489 & .2244 & & \\
\hline \multirow[t]{2}{*}{4.} & MSST & BEHAVIORAL & 17.113 & 2.6408 & .2156 & 298 & $16.069 * *$ \\
\hline & SST & BEHAVIORAL & 12.600 & 2.2043 & .1800 & & \\
\hline
\end{tabular}


From Table 3, it is clearly revealed that attitudes of mainstream school teachers differed significantly towards children with social (t- value 23.257, $\mathrm{P}<.001$ ), physical (t- value 10.451 , $\mathrm{P}<.001$ ) and behavioral ( $\mathrm{t}$-value 16.069, $\mathrm{P}<.001$ ) disabilities from those of special school. In other words teachers of main stream schools have more favorable attitudes toward such children (social, physical and behavioral disabilities) than those of special school, the reason may be that in special school the teachers used to deal with such children in their schools and might have to face so many problems. However insignificant difference $(t=1.398)$ in attitudes with regard to children with academic disability was found. It may be rather easy to handle mild mentally retarded children than children with social, physical and behavioral disabilities.

\section{CONCLUSION}

To sum up it may be stated that mainstream school teachers have more (overall) favorable attitudes toward children with various disabilities (physical, social and behavioral except academic) than the teachers of special school. However both groups have similar favorable attitudes toward children with academic disability revealing the fact that it may be rather easy to handle mentally retarded children than children with physical, social and behavioural disabilities. The present findings have highlighted the reason (i.e.less favourable attitudes of special school teachers) of slow progress in implementation of inclusive education in India. Hence there is a dire need to change the attitudes of teachers, who used to deal with such children, with adequate training, providing of proper resources, adequate classroom size and flexible curriculum.

\section{Acknowledgments}

The author appreciates all those who participated in the study and helped to facilitate the research process.

Conflict of Interests: The author declared no conflict of interests.

\section{REFERENCES}

Alghazo, M.E., \& Gaad, N.E. E. (2004). General education teachers in the United Arab Emirates and their acceptance of the inclusion of students with disabilities. British Journal of Special Education, 31(2), 94-99.

Ali, M. M., Mustapha, R., \& Jelas, M. Z.(2006). An Empirical study on teachers perceptions towards inclusive education in Malaysia. International Journal of Special Education, 21(3), 36-44.

Alur,M.(2001). Inclusion in the Indian Context. Humans cape, 8(6), 1-8

Beltrán, E.V. (1995), Roles of teachers - a case study based on: Diary of a language teacher.

Census of India Website : Office of the Registrar General \& Census Commissioner, India. (2017). Censusindia.gov.in. Retrieved 29 March 2017, from

http://www.censusindia.gov.in

(C) The International Journal of Indian Psychology, ISSN 2348-5396 (e) | ISSN: 2349-3429 (p) | 58 
Attitudes toward Inclusive Education among School Teachers: A Comparative Study

Chhabra, S., Srivastava, R., \& Srivastava, I.(2010). Inclusive education in Botswana: The perceptions of school teachers. Journal of Disability Policy Studies, 20(4), 219-228.

Croll, P., \& Moses, D., (2000). Ideologies and utopias: educational professionals views of inclusion. European Journal of Special Needs Education 15(1), 1-12.

Forlin, C., \& Chambers, D.(2011). Teacher preparation for inclusive education: Increasing knowledge but raising concerns. Asia-Pacific Journal Of Teacher Education, 39(1), 17-32.

Forlin, C., Kawai, N., \& Higuchi, S. (2015). Educational reform in Japan towards inclusion: are we training teachers for success? International Journal of Inclusive Education, 19(3), 314-331.

Forlin, C., Loreman, T., Sharma, U. \& Earle, C. (2009). Demographic differences in changing pre-service teachers' attitudes, sentiments and concerns about inclusive education. The International Journal of Inclusive Education, 13(2), 195-209.

Gaad, E.\& Khan, L.( 2007). Mainstream teachers attitudes towards inclusion of students with special educational needs in the private sector: A perspective from Dubai. International Journal of Special Education,22(2), 95-109.

Glaubman, R., \& Lifshitz, H. (2001). Ultra-orthodox Jewish teachers self efficacy and willingness for inclusion of pupils with special needs. European Journal of Special Needs Education.16, 207-223.

Hodkinson, A. (2006). Conceptions and misconceptions of inclusive education one year on: A critical analysis of newly qualified teachers knowledge and understanding of inclusion, Research in Education,76, 43-55.

Inclusion International (2009) Better education for all: when we're included too, a global report. Salamanca, Spain: University of Salamanca.

Johnson, A. (2001). Attitudes toward mainstreaming: Implications for in service training and teaching the handicapped. Education, 107(3), 229-233.

Kristensen, K., Loican-Omagor, M. \& Onen, N. (2003). The inclusion of learners with barriers to learning and development into ordinary school settings: a challenge for Uganda. British Journal of Special Education, 30(4), 194-201.

Kuyini, B.M., \& Desai, I. (2007). Principals ${ }^{\text {ee }}$ and teachers attitudes and knowledge of inclusive education as predictors of effective teaching practices in Ghana. Journal of Research in Special Educational Needs, 7(2), 104-113.

Loreman, T., Forlin, C., \& Sharma, U. (2007). An International Comparison of Pre-service Teacher Attitudes towards Inclusive Education. Disability Studies Quarterly, 27(4),

Loreman, T., Sharma, U., \& Forlin, C. (2013). Do pre-service teachers feel ready to teach in inclusive classrooms? A four country study of teaching self-efficacy. Australian Journal of Teacher Education, 38(1).

Mushoriwa, T. (2001). A study of attitudes of primary school teachers in Harare towards the inclusion of blind children in regular classes. British Journal of Special Education, 28, 142-147.

(C) The International Journal of Indian Psychology, ISSN 2348-5396 (e)| ISSN: 2349-3429 (p) | 59 


\section{Attitudes toward Inclusive Education among School Teachers: A Comparative Study}

National Curriculum Framework 2005, National Council of Educational Research and Training, New Delhi-110016.

Padeliadu \& Lampropolou(1997). Attitudes of special and regular education teachers, towards school integration. European Journal of Special needs education , 12(2),137-147.

Sarva Shiksha Abhiyan.” Sarva Shiksha Abhiyan: a programme for the universalization of inclusive education. Ministry of Human Resource Development, Department of School Education \& Literacy. Government of India. 2007. Web. 16 march, 2012. $<$ http://ssa.nic.in/>.

Sharma, U. (2012). Changing Pre-Service Teachers' Beliefs to Teach in Inclusive Classrooms in Victoria, Australia. Australian Journal of Teacher Education,37 (10), 53-66.

Sharma, U., Forlin, C. \& Loreman, T. (2008) 'Impact on training on pre-service teachers' attitudes and concerns about inclusive education and sentiments about persons with disabilities.' Disability \& Society, 23 (7),73-85.

Singal, N. (2006b). Adopting an ecosystemic approach for understanding inclusive education: An Indian case study. European Journal of Psychology of Education, Special issue: Ten years after Salamanca, 21(3), 239-252.

Singh \& Alur.(2001). Need of the hour-A paradigm shift in education .paper presented at the North South Dialogue on Inclusive Education, Mumbai, India.

Soodak, L. C., Podell, D. M. \& Lehman, L. R. (1998) 'Teacher, student, and school attributes as predictors of teachers' responses to inclusion.' The Journal of Special Education, 31 (4),480-97.

Stainback, W.C \& Stainback, S.B (Eds.) (1996). Controversial issues confronting special education: divergent perspectives. Boston: Allyn \& Bacon.

Tesfaye A. (2005).The attitudes of special and regular class teacher towards the inclusion individuals with mental retardation. Unpublished Masters Thesis. Addis Ababa. AAU press.

Whyte, B. (2005). Collaborating with diverse cultures. In D. Fraser, R. Moltzen, \& K. Ryba, (Eds.), Learners with special education needs in Aotearoa New Zealand (3rd ed.), 117-127.

Wilczenski, F. L. (1992). Development of a scale to measure attitude toward inclusive education. Educational and Psychological Measurement, 55(2), 291-299.

How to cite this article: Kumar A, Midha P (2017), Attitudes toward Inclusive Education among School Teachers: A Comparative Study, International Journal of Indian Psychology, Volume 4, Issue 2, No. 95, ISSN:2348-5396 (e), ISSN:2349-3429 (p), DIP:18.01.166/20170402, ISBN:978-1-365-84231-3 